\title{
Aquatic protists modulate the microbial activity associated with mineral surfaces and leaf litter
}

\author{
Ute Risse-Buhl ${ }^{1, *}$, Martina Karsubke ${ }^{1,2}$, Jeanette Schlief ${ }^{1}$, Christiane Baschien ${ }^{3}$, \\ Markus Weitere $^{2,4}$, Michael Mutz ${ }^{1}$
}

${ }^{1}$ Department of Freshwater Conservation, Brandenburg University of Technology Cottbus, 15526 Bad Saarow, Germany

${ }^{2}$ Department of General Ecology and Limnology, University of Cologne, 50674 Cologne, Germany

${ }^{3}$ Department of Environmental Technology, University of Technology Berlin, 10587 Berlin, Germany

${ }^{4}$ Department of River Ecology, Helmholtz Centre for Environmental Research-UFZ, 39114 Magdeburg, Germany

\begin{abstract}
Aquatic heterotrophic protists structure biofilm morphology and stimulate organic matter processing, but knowledge about their effects on the activity of surface-associated communities is still missing. Microcosm experiments revealed that the community respiration of young biofilms ( $7 \mathrm{~d}$ old) at mineral surfaces was not affected by co-cultivation with the raptorial feeder Chilodonella uncinata or the suspension feeder Tetrahymena pyriformis. However, grazing by both ciliates reduced the bacterial abundance and probably enhanced nutrient availability by recycling. Our data indicated an increased individual bacterial activity under grazing pressure, resulting in no net effect on the community respiration. In a second experiment, the respiration of leaf-associated microbial communities composed of the fungus Heliscus lugdunensis and a multispecies bacterial assemblage was significantly enhanced in the presence of T. pyriformis after $7 \mathrm{~d}$ of incubation. The stimulation was observed under both normoxic (turbulent) and hypoxic (turbulent and stagnant) conditions. After longer incubation, presumably matching an advanced phase of leaf degradation, T. pyriformis did not affect community respiration exposed to hypoxic stagnant conditions. In contrast to former studies, no impact of protists on leaf mass loss was observed. By stimulating leaf-associated community respiration, protists seem to affect processes involved in the initial phase of leaf processing.
\end{abstract}

KEY WORDS: Aquatic protists - Bacterial biofilms · Aquatic hyphomycete - Leaf litter decomposition $\cdot$ Respiration $\cdot$ Hypoxia

\section{INTRODUCTION}

Microbial communities consisting of prokaryotes, fungi, and protists (Lock et al. 1984) are rapidly formed at mineral surfaces (e.g. stones) or organic substrates (e.g. dead wood or leaf litter) submerged in water. In streams, these sites are hot spots of carbon turnover (Geesey et al. 1978). The microbial activity of biofilms at mineral surfaces is nourished by the dissolved organic carbon (DOC) in the surrounding water during the initial biofilm development (Mickleburgh et al. 1984, Sobczak 1996,
Romaní et al. 2004). To gain their required carbon, microbial communities on organic substrates utilize the organic substances of the wood or leaf tissue itself. The carbon fixed in bacteria and algae is then transferred by grazing protists to the meio- and macrofauna (Augspurger et al. 2008, Norf et al. 2009). The nutrients released from grazing protists can be directly available to the local biofilm community or lost to downstream sites due to water flow.

At mineral surfaces, grazing by protists increases the spatial and temporal heterogeneity of bacterial biofilms (Lawrence \& Snyder 1998). The grazing effi- 
ciencies of protists on biofilm bacteria depend on their mode of feeding. Raptorial feeders that take up selected food items can cause biofilm-free patches at mineral surfaces (Queck et al. 2006, Böhme et al. 2009). Strong feeding currents, created by suspension feeders to concentrate food items from the surrounding area, seem to cause distinct and densely colonized microcolonies (Weitere et al. 2005, Wey et al. 2008, Böhme et al. 2009). These micro-currents, generated either from moving cilia and eukaryotic flagella or from the protists mobility, are proposed to be responsible for enhanced nutrient and gas exchange between the biofilm and its surrounding fluid (Glud \& Fenchel 1999). Thus, protists may stimulate the microbial activity of biofilms both by grazing and associated nutrient recycling and by enhancing the availability of resources due to ventilation.

In contrast to biofilms that cover, for example, mineral surfaces, fungal hyphae and hyphosphereassociated bacteria also penetrate and grow inside the organic substrates, such as leaf litter (Baschien et al. 2009), and mediate its decomposition. Protists that rely mainly on a bacterial diet (Finlay \& Esteban 1998) are commonly found associated with leaf litter (Bott \& Kaplan 1989, Franco et al. 1998). Ribblett et al. (2005) showed that these flagellates and ciliates colonizing streams enhance bacterial leaf litter decomposition under normoxic conditions. Fungi, which are key microbial decomposers of leaf litter (Suberkropp 2001, Hieber \& Gessner 2002, Abelho et al. 2005), were not included in their experiment.

Microbial heterotrophic processes deplete oxygen and can cause hypoxic micro-zones within, for example, leaf packs (Eichem et al. 1993) or multi-layered biofilms at mineral surfaces (de Beer et al. 1996). The probability of the formation of hypoxic micro-zones increases in low-flow environments with poor resupply of oxygen, such as pools of low-order streams during drought conditions. Under hypoxic conditions, important leaf-processing macro-invertebrates, the shredders, stop feeding and may be eliminated (Boulton 2003, Bjelke 2005, Schlief \& Mutz 2009, 2011). Several protist species can tolerate low oxygen environments (Fenchel et al. 1989, Finlay \& Esteban 2009). Hence, protist-induced micro-currents, particularly under low oxygen conditions, possibly mitigate hypoxic micro-zones at leaf litter or mineral surfaces, and in combination with grazing activity, protists might modulate microbial activity. However, data on the impact of protists on microbial activity under hypoxic conditions are still limited.

In the present study, we investigated whether the microbial activity associated with submerged min- eral surfaces or leaf litter is affected by the presence of protists. At mineral surfaces, we tested the effects of 2 protist species with different feeding modes and grazing efficiencies (raptorial and suspension feeders) on biofilm activity. We hypothesized that, irrespective of the feeding mode of the protist species, the microbial activity associated with mineral surfaces is enhanced. Because microbial activity can expose leaf litter to low oxygen environments, we examined the effect of a protist on the leaf-associated microbial activity under different combinations of flow condition and oxygen concentration. We tested the hypothesis that leaf-associated microbial activity is most strongly enhanced by protists under hypoxic stagnant conditions because ventilating protists increase oxygen supply.

\section{MATERIALS AND METHODS}

Two experiments were performed to study the impact of protists on the microbial activity associated with (1) biofilms at a mineral surface (biofilm experiment) and (2) leaf litter (leaf litter experiment) (Table 1). In the biofilm experiment, protist species that differ in their mode of feeding (the raptorial feeding Chilodonella uncinata and the suspension feeding Tetrahymena pyriformis) were co-cultivated with a multispecies bacterial community on a mineral surface (glass slide) in 2 successively conducted runs. In the leaf litter experiment, the impact of a protist on microbial activity associated with leaf litter under different combinations of oxygen concentration and flow condition was studied. T. pyriformis was chosen as a model species because leaf-associated ciliate communities in small streams are dominated by suspension feeding species (Franco et al. 1998). Community respiration was used as a microbial response parameter to estimate microbial activity associated with the mineral surface and leaf litter. The abundance and biomass of protists and bacteria were assessed to support the results on microbial activity. In the leaf litter experiment, remaining leaf mass was used as a measure for microbially mediated leaf decay.

\section{Cultivation of protists and bacteria}

The raptorial feeder Chilodonella uncinata (Phyllopharyngia, Ciliophora) is characterized by a special mouth structure, the cytopharyngeal basket with phyllae and rod-shaped nematodesmata, and a 
dorso-ventrally flattened cell shape with cilia mainly on the ventral side (Foissner et al. 1991, Hausmann et al. 2003). Due to its specialized morphology, this ciliate species is a typical component of biofilms (Foissner et al. 1991, Risse-Buhl \& Küsel 2009) and can take up surface-associated bacteria. The suspension feeder Tetrahymena pyriformis (Hymenostomatia, Ciliophora) creates strong water currents with a ciliary membranelle that transports mainly suspended but also loosely attached bacterial cells to the mouth region (Foissner et al. 1994, Eisenmann et al. 1998). This species changes frequently between a biofilm and planktonic lifestyle. The genus Tetrahymena can profoundly alter the 3-dimensional structure of bacterial biofilms (Weitere et al. 2005). Cyst formation is not described for either species (see Foissner et al. 1991, 1994).

Chilodonella uncinata was isolated from sandy sediments (upper $1 \mathrm{~cm}$ ) of the Hühnerwasser Creek (Brandenburg, Germany; 51 $36^{\prime} \mathrm{N}, 14^{\circ} 17^{\prime} \mathrm{E}$ ) by serial dilution. Cultures were kept in Volvic table water $\left(\mathrm{NO}_{3}{ }^{-} 6.3 \mathrm{mg} \mathrm{l}^{-1}, \mathrm{PO}_{4}{ }^{3-} 0.63 \mathrm{mg} \mathrm{l}^{-1}, \mathrm{SO}_{4}{ }^{2-} 8.1 \mathrm{mg} \mathrm{l}^{-1}\right.$; Dufrêne \& Legendre 1997) with a few sterilized quinoa grains. Axenic cultures of Tetrahymena pyriformis (strain 1630/1W, CCAP, Windermere, UK) were kept in sterilized Proteose Peptone Yeast Extract medium (PPY, $20 \mathrm{~g} \mathrm{l}^{-1}$ Proteose peptone and $2.5 \mathrm{~g} \mathrm{l}^{-1}$ yeast extract, dissolved in deionized water that was obtained by reverse osmosis). The cultures were kept at $18 \pm 2^{\circ} \mathrm{C}$, and cells were transferred to fresh medium every $2 \mathrm{wk}$. To enrich the protist cells, cultures of $C$. uncinata were filtered (pore size $8 \mu \mathrm{m}$, cellulose nitrate membrane) $1 \mathrm{~d}$ before the experiment started. Protists could recover overnight and further minimize associated bacteria. Lugol-fixed samples from both protist cultures were used for enumeration at $100 \times$ magnification (Axioplan, Zeiss).

A multispecies bacterial community that originated from Volvic table water (initial bacterial abundance $<10^{4}$ cells ml ${ }^{-1}$ ) was used for the biofilm formation at mineral surfaces in the biofilm experiment. A culture of $50 \mathrm{ml}$ of Volvic table water with 10 quinoa grains (VQ bacterial community) was left undisturbed over a period of $3 \mathrm{~d}$ (cf. Böhme et al. 2009). A multispecies bacterial community originating in the Dikopsbach Stream (a tributary of the River Rhine, near Wesseling, North Rhine-Westphalia, Germany; 50 $49^{\prime} \mathrm{N}$, $\left.6^{\circ} 59^{\prime} \mathrm{E}\right)$ was used in the leaf litter experiment to mimic the bacterial community composition typically found in forested streams. The water was sampled in stream sections where leaf litter accumulated. The bacterial community was enriched by serial dilution, cultivated in Pratt medium $\left(0.1 \mathrm{~g} \mathrm{l}^{-1} \mathrm{KNO}_{3}, 0.01 \mathrm{~g} \mathrm{l}^{-1}\right.$ $\mathrm{K}_{2} \mathrm{HPO}_{4}, 0.01 \mathrm{~g} \mathrm{l}^{-1} \mathrm{MgSO}_{4}$, and $0.001 \mathrm{~g} \mathrm{l}^{-1} \mathrm{FeCl}_{3}$ ) with quinoa grains (DPQ bacterial community) and transferred to fresh medium every $2 \mathrm{wk}$. All cultures were kept at $18^{\circ} \mathrm{C}$ in the dark. The bacteria were enumerated in both the bacterial and Chilodonella uncinata

Table 1. Experimental design and characteristics of protist species and bacterial communities used for the 2 experiments. VQ bacterial community: a bacterial community developed in Volvic table water with quinoa grains within 3 d. DPQ bacterial community: a bacterial community that was enriched from the Diekopsbach stream (forested stream with high leaf litter input) by serial dilution and cultivated in Pratt medium with quinoa grains within $3 \mathrm{~d}$

\begin{tabular}{|c|c|c|c|c|c|}
\hline Protist species $^{\mathrm{a}}$ & $\begin{array}{l}\text { Feeding mode } \\
\text { food source }\end{array}$ & $\begin{array}{l}\text { Bacterial } \\
\text { community }\end{array}$ & $\begin{array}{l}\text { Surface or } \\
\text { substrate }\end{array}$ & $\begin{array}{c}\text { Oxygen }+ \\
\text { flow environment }\end{array}$ & $\begin{array}{l}\text { Duration }(\mathrm{d}) \\
\text { replication }\end{array}$ \\
\hline $\begin{array}{l}\text { Biofilm experiment } \\
\text { Chilodonella uncinata } \\
\text { (Phyllopharyngia, } \\
\text { Ciliophora) }\end{array}$ & $\begin{array}{c}\text { Raptorial feeder; } \\
\text { loosely attached } \\
\text { and embedded bacteria }\end{array}$ & $\begin{array}{l}\text { VQ bacterial } \\
\text { community }\end{array}$ & $\begin{array}{l}\text { Mineral surface } \\
\text { (glass slide) }\end{array}$ & $\begin{array}{c}\text { Normoxia } \\
+ \text { turbulent flow }\end{array}$ & $\begin{array}{c}7 \\
\mathrm{n}=5\end{array}$ \\
\hline $\begin{array}{l}\text { Tetrahymena pyriformis } \\
\text { (Hymenostomatia, } \\
\text { Ciliophora) }\end{array}$ & $\begin{array}{l}\text { Suspension feeder; } \\
\text { suspended and } \\
\text { loosely attached bacteria }\end{array}$ & $\begin{array}{l}\text { VQ bacterial } \\
\text { community }\end{array}$ & $\begin{array}{l}\text { Mineral surface } \\
\text { (glass slide) }\end{array}$ & $\begin{array}{c}\text { Normoxia } \\
+ \text { turbulent flow }\end{array}$ & $\begin{array}{c}7 \\
\mathrm{n}=5\end{array}$ \\
\hline $\begin{array}{l}\text { Leaf litter experiment } \\
\text { Tetrahymena pyriformis } \\
\text { (Hymenostomatia, } \\
\text { Ciliophora) }\end{array}$ & $\begin{array}{l}\text { Suspension feeder; } \\
\text { suspended and } \\
\text { loosely attached bacteria }\end{array}$ & $\begin{array}{l}\text { DPQ bacterial } \\
\text { community }\end{array}$ & $\begin{array}{c}\text { Leaf litter } \\
\text { (leaves of } \\
\text { Alnus glutinosa } \\
\text { colonized } \\
\text { with aquatic } \\
\text { hyphomycete } \\
\text { Heliscus lugdunensis) }\end{array}$ & $\begin{array}{c}\text { Normoxia } \\
+ \text { turbulent flow } \\
\text { Hypoxia } \\
+ \text { turbulent flow } \\
\text { Hypoxia + stagnant }\end{array}$ & $\begin{array}{c}7 \& 21 \\
n=3\end{array}$ \\
\hline
\end{tabular}


cultures before the experiments started (see counting method in 'Biofilm experiment').

Heliscus lugdunensis (Ascomycota, Fungi; CCM F10507, Brno, Czech Republic), an aquatic hyphomycete colonizing decaying plant litter (Willoughby \& Archer 1973), was used in the leaf litter experiment. The hyphomycete was cultivated on malt extract agar (Gams et al. 1998), and conidia of the fungus were harvested by flooding the Petri dish with distilled water after $7 \mathrm{~d}$. Subsequently, the conidia were suspended in $400 \mathrm{ml}$ of malt extract broth at a density of $5.0 \times 10^{5}$ conidia $\mathrm{ml}^{-1}$.

\section{Biofilm experiment}

For the biofilm experiment, sterile plastic centrifuge tubes $(50 \mathrm{ml}$, Sarstedt) equipped with a glass slide $(76 \times 26 \mathrm{~mm})$ for biofilm formation at a mineral surface served as microcosms. The slides, which fitted the diameter of the entire tube, divided the tube in 2 water volumes connected at both ends. Air was pumped into the microcosms through a hollow needle (stainless steel, length $200 \mathrm{~mm}$, inner diameter $2 \mathrm{~mm}$ ) at a rate of $0.2 \mathrm{~cm}^{3} \mathrm{~s}^{-1}$ to maintain oxygen saturation and generate a turbulent water flow circulating the glass slides. The opening of the hollow needle was placed above the lower end of the glass slide. Because the tubes were placed in a slanting position $\left(\sim 20^{\circ}\right)$, the air bubbles rising from the needle opening travelled along the tube wall and had no contact with the glass slides. Two sterile syringe filters $(0.2 \mu \mathrm{m})$ placed in the airflow prevented microbial contamination of the microcosms. A cover slip $(20 \times 20 \mathrm{~mm})$, which was tightly fixed with silicone on each glass slide, was used to sample and enumerate biofilmassociated protists in a defined area at the end of the biofilm experiment. Comparable microbial communities were expected on both cover slips and glass slides because both are of the same material with identical surface properties and were handled in the same way.

The experimental design of the biofilm experiment is shown in Table 1. The microcosms were equipped with Volvic table water (UV sterilized, $\mathrm{pH} 7$ ) and 3 to 5 sterile quinoa grains. The grains that were added once at the start of the experiment accumulated at the bottom of the microcosm tubes, creating carbon-rich areas. From here, dissolved carbon was transported via the circulating turbulent water flow towards the mineral surface; thus, associated bacteria were continuously supplied with a carbon source. The microcosms were inoculated with a suspension of the VQ bacterial community of $0.6 \times 10^{10}$ to $1.2 \times 10^{10}$ cells ml ${ }^{-1}$. In the protist-free treatment, bacterial biofilms developed at the mineral surface. Two successive runs were performed in which the protist-inhabited treatment immediately received a suspension of either Chilodonella uncinata or Tetrahymena pyriformis. Initial protist abundances ranged between 193 and 208 cells ml$^{-1}$ (see Table 2). Bacteria in the overnight-recovered C. uncinata cultures were quantified $\left(3.1 \times 10^{9}\right.$ cells $\mathrm{ml}^{-1}$ ) and added at the same amount to the corresponding protist-free microcosms. Due to the additional bacteria in the protist culture, the initial bacterial abundance in the $C$. uncinata run was 10 -fold higher than in the $T$. pyriformis run. The volume added for T. pyriformis was kept as low as possible $(100 \mu \mathrm{l})$ to minimize the effects of the culture medium on the experiment. The 2 treatments (protist-free and protist-inhabited biofilms) were replicated 5 times to accurately compare the treatments. The experiment was kept at $18 \pm 1^{\circ} \mathrm{C}$ in the dark. Microcosms were run as continuous-batch systems to keep protists and their bacterial prey in a growing and reproductive state. After 3 and $6 \mathrm{~d}$, half of the medium was carefully replaced via the hollow needle to remove waste products and to guarantee the supply of nutrients.

After replenishing the medium, the microcosms were left overnight to recover before the biofilms were sampled at Day 7. Prior to the respiration measurement, the cover slip was carefully removed from the exposed glass slide and placed on a new glass slide to enumerate the associated protist cells. The protist cells were fixed with Lugol's solution, and the whole cover slip was scanned. The respiration rates of microbial biofilms and the corresponding suspensions were measured after a $7 \mathrm{~d}$ incubation period to observe the potential effects of protists on all compartments (biofilm and suspension) of the microcosm (for measurement details, please refer to 'Respiration measurement'). After the respiration rate measurements, the glass slides with associated biofilm bacteria were placed in a formaldehyde solution (final concentration $3.7 \%$ ) and kept at $4^{\circ} \mathrm{C}$ until further processing. Suspended protists and bacterial cells were enumerated in the removed medium at Days 3 and 6. The suspended protistan and bacterial cells in the removed medium were fixed with Lugol's solution and formaldehyde, respectively. The fixed suspended protists were observed in Utermoehl chambers at $100 x$ or $200 x$ magnification. Biofilm-covered glass slides were incubated in the surfactant Triton X100 (final con- 
centration $0.1 \mathrm{mM}$ ) for $24 \mathrm{~h}$ and treated in a sonication bath (Elma Transonic Digital Type T790/H) 4 times for 30 min each at maximum power to disrupt the biofilm matrix and separate bacterial cells from the glass slide surface (Velji \& Albright 1993, Chen \& Stewart 2000). Samples that were placed for a longer time period in the sonication bath showed a similar bacterial abundance. We concluded that the majority of biofilm bacteria were detached from the mineral surface by the applied procedure. The bacterial cells were stained with DAPI $\left(4^{\prime}, 6\right.$-diamidino2-phenylindol, final concentration $1 \mu \mathrm{g} \mathrm{ml}^{-1}$; Porter \& Feig 1980, modified after Nixdorf \& Jander 2003). At least 400 cells were counted using epifluorescence microscopy at 1000× magnification.

\section{Leaf litter experiment}

For this experiment, freshly fallen leaves of Alnus glutinosa (Fagales, Angiospermae) were collected with nets within $24 \mathrm{~h}$ after abscission in autumn 2008. The leaves were air-dried and stored at room temperature in the dark until the experiment started. The leaves were then cut into discs of $\varnothing 2.2 \mathrm{~cm}$. The leaf discs were autoclaved for $30 \mathrm{~min}$ to ensure their sterility and uniform starting conditions to facilitate the observation of the treatment effects. After $24 \mathrm{~h}$ leaching in sterile deionized water, a total of 120 leaf discs were transferred to the liquid culture of the aquatic hyphomycete Heliscus lugdunensis and left aerated in the dark for $3 \mathrm{wk}$ to allow their colonization (Chauvet \& Suberkropp 1998). Subsequently, the leaf discs, colonized with the aquatic hyphomycete, were placed in Erlenmeyer flasks $(100 \mathrm{ml})$ equipped with $50 \mathrm{ml}$ of sterile Pratt medium. Each of the 36 flasks received 3 leaf discs and $200 \mu$ of suspension of the DPQ bacterial community (final abundance $6.4 \times 10^{4}$ cells $\mathrm{ml}^{-1}$ ). Eighteen flasks served as a protist-free treatment, and the other 18 flasks immediately received a suspension of the culture of Tetrahymena pyriformis (protist-inhabited leaves, final protist abundance of $1.7 \times 10^{2} \pm 0.6 \times 10^{2}$ cells $\mathrm{ml}^{-1}$ ). The Erlenmeyer flasks were sealed with rubber plugs. Two hollow needles allowed gas exchange through sterile filters (pore size $0.2 \mu \mathrm{m}$, as described above) and a weekly exchange of the medium.

In streams, leaves are exposed to a range of environmental conditions, such as different flow regimes varying from stagnant conditions to turbulent flow and oxygen concentrations varying from anoxic to hypoxic. Thus, we designed the following treatments for factor combinations of oxygen concentration and flow condition (OC/FC): (1) normoxia and turbulent flow, (2) hypoxia and turbulent flow, and (3) hypoxia and stagnant conditions (Table 1). Each treatment was replicated 3 times. To maintain the desired factor combinations from the start of the experiment onward, the microcosms were aerated either with ambient air or nitrogen gas. The oxygen concentration in the microcosms was checked daily with oxygen optodes (Fibox, PreSens-Precision Sensing). Average oxygen levels in normoxic treatments of $10.0 \pm 0.5 \mathrm{mg} \mathrm{l}^{-1}$ and in hypoxic treatments of $1.2 \pm$ $0.6 \mathrm{mg} \mathrm{l}^{-1}$ were achieved throughout the experiment. The turbulent flow was achieved by shaking on a circular-shaker at 100 rounds $\mathrm{min}^{-1}$.

The leaf-associated Tetrahymena pyriformis were sampled in direct proximity of the leaf surface with a syringe, fixed with Lugol's solution, and enumerated at $100 \times$ magnification. One disc was fixed in formaldehyde (final concentration 3.7\%) for the enumeration of bacteria. An ultrasonic probe (Sonoplus UW 2070, Bandelin electronics) was placed in the sample for $30 \mathrm{~s}$ at $30 \%$ of the maximum power to separate bacterial cells from the leaves (Velji \& Albright 1993). The quantification of bacteria was performed as described above. Two of the 3 leaf discs were used to determine ash-free dry mass (AFDM) by combusting at $400^{\circ} \mathrm{C}$ for $4 \mathrm{~h}$. Additionally, the initial AFDM (AFDM initial $)$ of 4 leaf discs colonized with the fungus was determined. The difference between the AFDM initial $_{\text {and AFDM after } 7 \text { or }}$ $21 \mathrm{~d}$ was calculated and is presented as the remaining AFDM (AFDM remaining $_{\text {. The suspended protists }}$ and bacteria were enumerated as described above.

\section{Respiration measurement}

The respiration of the whole community was measured as a microbial response parameter to detect the effect of protists on microbial activity. Closedchamber systems were used to register the oxygen decrease over time with oxygen optodes (Oxy-10, PreSens-Precision Sensing) under a constant temperature of $18^{\circ} \mathrm{C}$ and normoxic (100\% oxygen saturation) conditions. The biofilms at the mineral surfaces were placed in respiration chambers equipped with fresh Volvic table water $(20 \mathrm{ml})$. Internal water circulation maintained by a diaphragm metering pump (frequency $90 \mathrm{~Hz}$, intensity 40 \%; GALa 1602, ProMinent) guaranteed continuous advection. Data are presented per area of the mineral surface (community respiration of biofilms per surface area, $\mathrm{CR}_{\mathrm{B}}$ ). The respiration of the suspensions $(50 \mathrm{ml})$ of the biofilm experiment 
(community respiration of the suspension per volume, $\mathrm{CR}_{\mathrm{S}}$ ) and of 3 leaf discs of the leaf litter experiment placed in $50 \mathrm{ml}$ of fresh Pratt medium were measured in glass bottles (Schlief \& Mutz 2007). Continuous advection was maintained by adding glass spheres (Ø $16 \mathrm{~mm}$ ) that moved in the gently stirred glass bottles to avoid oxygen depletion near the optode location. The initial oxygen concentration of all samples was adjusted to 7.5 to $9.5 \mathrm{mg}^{-1}$ to compare the respiration measurements of the 2 experiments, although incubations of the leaf litter experiment were conducted under normoxic or hypoxic conditions. The respiration rates of the leaf litter experiment are represented as potential community respiration associated with leaves $\left(\mathrm{pCR}_{\mathrm{LA}}\right)$ because all treatments (normoxic and hypoxic) were measured at oxygen saturation. An oxygen decrease of at least $1 \mathrm{mg} \mathrm{l}^{-1}$ was monitored in each of the 5 replicates of the biofilm experiment or the 3 replicates of the leaf litter experiment at intervals of measurements that ranged from 10 to $15 \mathrm{~min}$ for periods of 3 to $4 \mathrm{~h}$.

\section{Data exploitation and statistical analyses}

Community respiration rates were calculated from linear regressions of oxygen decrease over time and related to a defined surface area of the biofilm and leaf disc or volume of the suspension.

The length and width of 25 cells of each protist species were determined microscopically (mean length $\times$ width: Chilodonella uncinata $33 \times 21 \mu \mathrm{m}$, Tetrahymena pyriformis $30 \times 18 \mu \mathrm{m})$. The biovolumes were calculated assuming a half-spheroid and spheroid cell shape for $C$. uncinata and T. pyriformis, respectively. The biovolumes were divided by 0.4 to correct for shrinkage caused by the fixation with Lugol's solution (Jerome et al. 1993). Corrected values were then used to calculate the biomass of single protist cells with the published conversion factor of $0.11 \times 10^{-6} \mu \mathrm{g} \mathrm{C} \mathrm{mm}^{-3}$ (Turley et al. 1986). The biovolume of $C$. uncinata and T. pyriformis was estimated as $7.9 \times 10^{4} \mu \mathrm{m}^{3}$ and $9.8 \times 10^{4} \mu \mathrm{m}^{3}$ and the biomass was estimated as $0.87 \times 10^{-2} \mu \mathrm{g} \mathrm{C}$ cell $^{-1}$ and $1.07 \times$ $10^{-2} \mu \mathrm{g} \mathrm{C}$ cell $^{-1}$, respectively. In the biofilm experiment, the generation time $\left(t_{\mathrm{g}}\right)$ of suspended protists was calculated as follows:

$$
t_{\mathrm{g}}=\ln (2) / \mu
$$

The growth rate $(\mu)$ was calculated as follows:

$$
\mu=\left[\ln \left(a_{t+1}\right)-\ln \left(a_{t}\right)\right] / t
$$

where $a_{t}$ is either the protists abundance at the start of the experiment or after replenishing the medium at Day 3 , and $a_{t+1}$ is the protists abundances at Day 3 or 6 , respectively. The $a_{t}$ at Day 3 was calculated assuming that the number of suspended cells was diluted $50 \%$ by replenishing the medium.

In the biofilm experiment, pictures of DAPI-stained bacteria from each replicate were analyzed with image analysis software (AnalySIS 3.2 software, Olympus) to calculate the bacterial biovolume. Up to 550 bacterial cells per replicate were observed. The mean biovolume of single bacterial cells in the presence of Chilodonella uncinata and Tetrahymena pyriformis was $0.22 \pm 0.09$ (mean $\pm \mathrm{SD}$ ) and $0.11 \pm$ $0.01 \mathrm{\mu m}^{3} \mathrm{cell}^{-1}$ and in the protist-free treatment 0.08 \pm 0.02 and $0.10 \pm 0.02 \mu^{3}$ cell $^{-1}$, respectively. The biovolume data of the corresponding replicate were used to calculate the biovolume-specific bacterial biomass (Loferer-Krößbacher et al. 1998).

Comparisons of community respiration rates, bacterial abundances, and biomass between protist-free and protist-inhabited treatments of one run were performed using a Student's $t$-test ( $\mathrm{R}$, version 2.10.1). A 2-sided Fisher's F-test was used to compare the variance of the community respiration rates of the protist-inhabited and protist-free treatments. The runs of the biofilm experiment with different protist species were not statistically compared due to different starting concentrations of bacteria. A 2-factorial analysis of variance (ANOVA) was used to test the effects of time and the factor combination OC/FC on suspended and leaf-associated protist abundances as well as the effects of protist presence and the factor combination OC/FC on suspended and leaf-associated bacteria, respiration rates, and AFDM remaining $_{\text {. }}$

\section{RESULTS}

\section{Protists and bacterial abundance and biomass in the biofilm experiment}

Biofilms at mineral surfaces were densely colonized with cells of the raptorial feeder Chilodonella uncinata, reaching abundances of $102.8 \pm 46.0$ cells $\mathrm{cm}^{-2}$ (Table 2). The abundance of Tetrahymena pyriformis associated with mineral surfaces was similar to that of $C$. uncinata and reached $146.3 \pm 85.7$ cells $\mathrm{cm}^{-2}$. Resting stages or cysts of ciliates were not observed in the microcosms.

The presence of both of the protist species had a significant negative effect on the abundance and biomass of biofilm bacteria ( $t$-test: $\mathrm{p}<0.01)$. Overall, the abundance of biofilm bacteria ranged between $0.96 \times$ 
Table 2. Abundances of protists and bacteria in the suspension (Day 0 and 6) and in biofilms at mineral surfaces (Day 7 ) in the biofilm experiment. Abundances at Day 0 are single counts; all other values are means $( \pm$ standard deviation shown in parentheses) $(n=5)$. $-P$ : treatments without grazing protists; $+P$ : treatments with grazing protists; na: not applicable

\begin{tabular}{|c|c|c|c|c|c|}
\hline \multirow{2}{*}{ Biofilm experiment } & \multirow[t]{2}{*}{ Day } & \multicolumn{2}{|c|}{ - Suspension } & \multicolumn{2}{|c|}{ - Biofilm } \\
\hline & & $\left(\right.$ cells ml $l^{-1}$ ) & $\left(\mu \mathrm{g} \mathrm{C} \mathrm{m}{ }^{-1}\right)$ & $\left(\right.$ cells cm ${ }^{-2}$ ) & $\left(\mu \mathrm{g} \mathrm{C} \mathrm{cm}{ }^{-2}\right)$ \\
\hline \multicolumn{6}{|l|}{ Raptorial feeder } \\
\hline \multirow[t]{2}{*}{ Chilodonella uncinata } & 0 & 207.8 & 2.28 & na & na \\
\hline & $6 / 7$ & $4.3(0.7)$ & $0.05(0.01)$ & $102.8(46.0)$ & $1.13(0.50)$ \\
\hline VQ medium bacteria & 0 & $9.57 \times 10^{7}$ & 3.828 & na & na \\
\hline$-\mathrm{P}$ & $6 / 7$ & $2.07(0.21) \times 10^{6}$ & $0.051(0.011)$ & $2.97(0.57) \times 10^{6}$ & $0.054(0.017)$ \\
\hline$+\mathrm{P}$ & $6 / 7$ & $8.62(1.86) \times 10^{6}$ & $0.500(0.300)$ & $0.96(0.17) \times 10^{6}$ & $0.036(0.009)$ \\
\hline \multicolumn{6}{|l|}{ Suspension feeder } \\
\hline \multirow[t]{2}{*}{ Tetrahymena pyriformis } & 0 & 193.0 & 2.24 & na & na \\
\hline & $6 / 7$ & $1435.1(181.2)$ & $16.66(2.10)$ & $146.3(85.7)$ & $1.70(0.99)$ \\
\hline VQ medium bacteria & 0 & $1.11 \times 10^{7}$ & 0.341 & na & na \\
\hline$-\mathrm{P}$ & $6 / 7$ & $2.59(0.99) \times 10^{6}$ & $0.075(0.029)$ & $4.97(1.48) \times 10^{6}$ & $0.090(0.038)$ \\
\hline$+\mathrm{P}$ & $6 / 7$ & $0.86(0.58) \times 10^{6}$ & $0.028(0.019)$ & $1.45(0.65) \times 10^{6}$ & $0.022(0.006)$ \\
\hline
\end{tabular}

$10^{6} \pm 0.17 \times 10^{6}$ and $4.97 \times 10^{6} \pm 1.48 \times 10^{6}$ cells cm$^{-2}$. Biofilm bacteria were 3.1- and 3.4-fold less abundant and the biomass of biofilm bacteria was 1.5- and 4.1fold lower in the presence of Chilodonella uncinata and Tetrahymena pyriformis compared to the protistfree treatment, respectively (Table 2). The bacterial biomass in the protist-inhabited biofilms of C. uncinata and T. pyriformis contributed 3.1 and $1.3 \%$, respectively, to the community biomass of biofilms. The presence of $C$. uncinata significantly affected the bacterial biovolume ( $t$-test: $\mathrm{p}<0.001)$. In the protist-inhabited biofilms, $36.6 \%$ of bacteria had a biovolume $\geq 0.2 \mathrm{\mu m}^{3}$, while in the protist-free biofilms, only $3.4 \%$ of the bacteria were $\geq 0.2 \mu \mathrm{m}^{3}$ (Fig. 1). The presence of $T$. pyriformis did not alter the bacterial biovolume ( $t$-test: $\mathrm{p}=0.49$ ). In both treatments of the $T$. pyriformis run, over $70 \%$ of the bacterial cells were $<0.2 \mathrm{\mu m}^{3}$.

The abundance of Chilodonella uncinata in suspension was $<5$ cells $\mathrm{ml}^{-1}$ after 3 and $6 \mathrm{~d}$. Due to their low abundance, $C$. uncinata contributed $8.6 \pm 7.5 \%$ to the suspended microbial community. Because $91.4 \pm 7.5 \%$ of the cells of $C$. uncinata in the microcosm were observed associated with the mineral surface (Table 2), medium exchange had a marginal effect on the protist population in the microcosms. The suspension feeder Tetrahymena pyriformis preferably colonized the suspension, with $91.1 \pm 4.8 \%$ of all cells in the microcosm. The abundance of suspended T. pyriformis increased from 816 \pm 99 cells ml $^{-1}$ at Day 3 to $1435 \pm 181$ cells ml $^{-1}$ at Day 6. The generation time of the suspended T. pyriformis population was estimated as $30.6 \pm 2.5 \mathrm{~h}$ between the

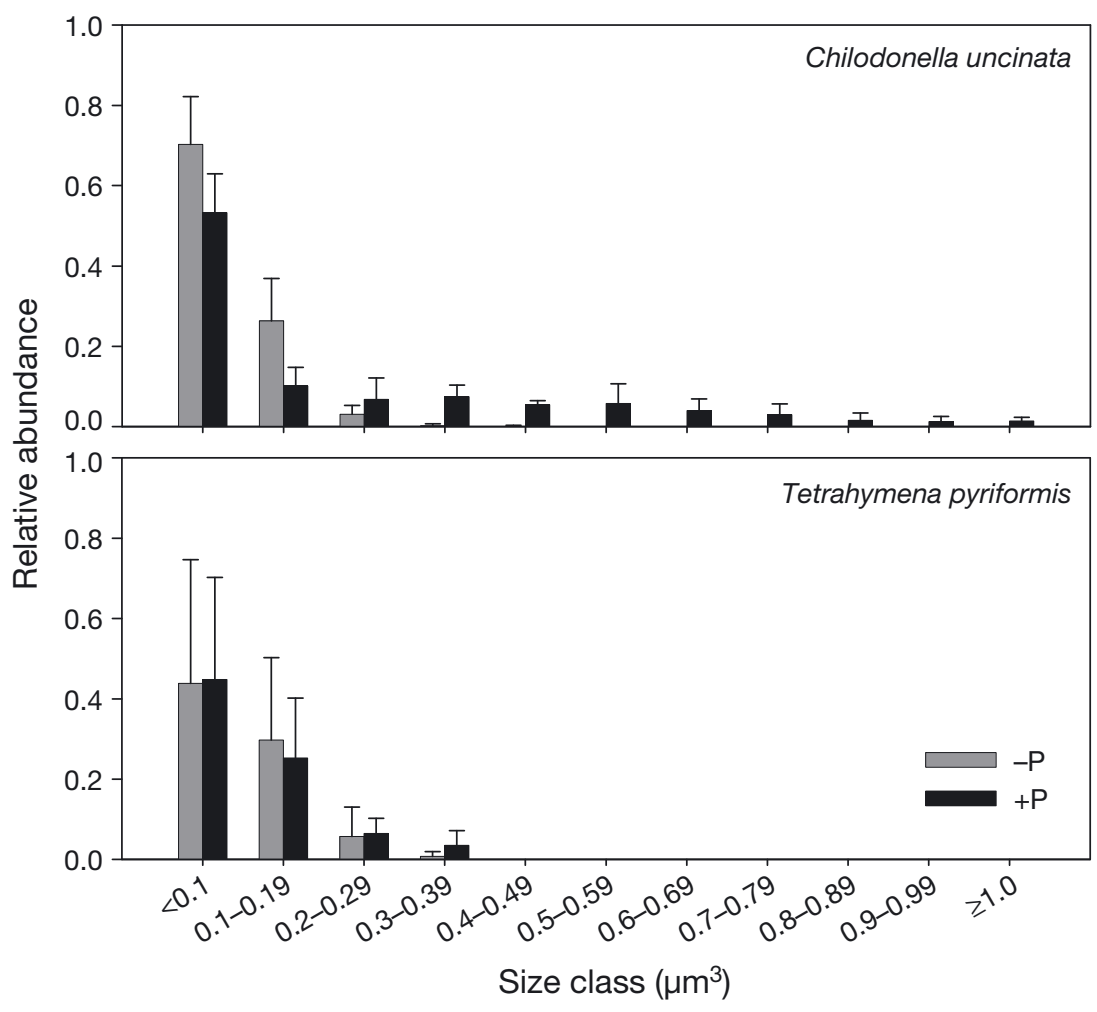

Fig. 1. Relative abundance of biovolume size classes $\left(\mu^{3}\right)$ of the VQ bacterial community in protist-free $(-\mathrm{P})$ and protist-inhabited $(+\mathrm{P})$ biofilms after $7 \mathrm{~d}$ of incubation (mean \pm standard deviation, $\mathrm{n}=5$ ). Data were normalized by the total number of analyzed bacterial cells 
start of the experiment and Day 3, and after replenishing the medium at Day 3 and Day 6, the generation time reached $45.8 \pm 8.5 \mathrm{~h}$. Losses of the suspended protist population due to replenishing half of the medium were compensated within 1 to $2 \mathrm{~d}$. Thus, the suspended T. pyriformis population was kept in a reproducing phase.

Bacterial abundance in the protist-free control ranged between $2.07 \times 10^{6} \pm 0.21 \times 10^{6}$ and $2.59 \times 10^{6}$ $\pm 0.99 \times 10^{6}$ cells $\mathrm{ml}^{-1}$ in both runs of the biofilm experiment (Table 2). After $6 \mathrm{~d}$ of incubation, bacterial cell numbers were comparable between both runs despite the initially higher bacterial abundance in the Chilodonella uncinata run. In the treatment with $C$. uncinata, the abundance of suspended bacteria was significantly higher than in the protist-free treatment ( $t$-test: $p=0.001$; Table 2). Highly abundant suspended Tetrahymena pyriformis caused a significantly lower abundance of suspended bacteria compared to the protist-free treatment ( $t$-test: $\mathrm{p}=0.019$ ).

\section{Community respiration in the biofilm experiment}

In both runs, the $\mathrm{CR}_{\mathrm{B}}$ was not significantly different between the protist-free and protist-inhabited biofilms ( $t$-test: $\mathrm{p}>0.05$ ). Mean rates of $\mathrm{CR}_{\mathrm{B}}$ ranged between $0.8 \times 10^{-4} \pm 0.3 \times 10^{-4}$ and $1.3 \times 10^{-4} \pm 0.9 \times$
$10^{-4} \mathrm{mg} \mathrm{O}_{2} \mathrm{~h}^{-1} \mathrm{~cm}^{-2}$ (Fig. 2a). Interestingly, the variance of $\mathrm{CR}_{\mathrm{B}}$ was 12.9 -fold ( $F$-test: $\mathrm{p}=0.030$ ) and 11.0fold (F-test: $\mathrm{p}=0.039$ ) larger in treatments with Chilodonella uncinata and Tetrahymena pyriformis, respectively, than in protist-free treatments.

In suspension, the mean $\mathrm{CR}_{\mathrm{S}}$ ranged between $2.6 \times$ $10^{-4} \pm 0.6 \times 10^{-4}$ and $4.0 \times 10^{-4} \pm 0.6 \times 10^{-4} \mathrm{mg} \mathrm{O}_{2} \mathrm{ml}^{-1}$ $\mathrm{h}^{-1}$ (Fig. 2b). In both runs, the $\mathrm{CR}_{\mathrm{S}}$ (t-test: $\mathrm{p}>0.05$ ) and variance of the $\mathrm{CR}_{\mathrm{S}}$ (F-test: $\left.\mathrm{p}>0.05\right)$ were not affected by the protists. Overall, the $\mathrm{CR}_{\mathrm{S}}$ was 1.5 -fold higher in the run with Chilodonella uncinata than in the run with Tetrahymena pyriformis.

\section{Protist abundance, bacterial abundance and remaining leaf mass in the leaf litter experiment}

The factor combination OC/FC had no significant effect on the abundance of leaf-associated (ANOVA: $F=4.017, \mathrm{df}=1, \mathrm{p}=0.065$ ) and suspended (ANOVA: $F=0.322, \mathrm{df}=1, \mathrm{p}=0.579$ ) Tetrahymena pyriformis. Up to $6.5 \times 10^{3}$ cells $\mathrm{ml}^{-1}$ were associated with leaves (Fig. 3a), and up to $3.8 \times 10^{3}$ cells $\mathrm{ml}^{-1}$ (Fig. $3 \mathrm{~b}$ ) were recorded in suspension. At Day 7 , significantly more cells of $T$. pyriformis colonized the exposed leaves (ANOVA: $F=7.900, \mathrm{df}=1, \mathrm{p}=0.014$ ) and the suspension (ANOVA: $F=12.137$, df $=1, \mathrm{p}=0.004$ ) than at Day 21.
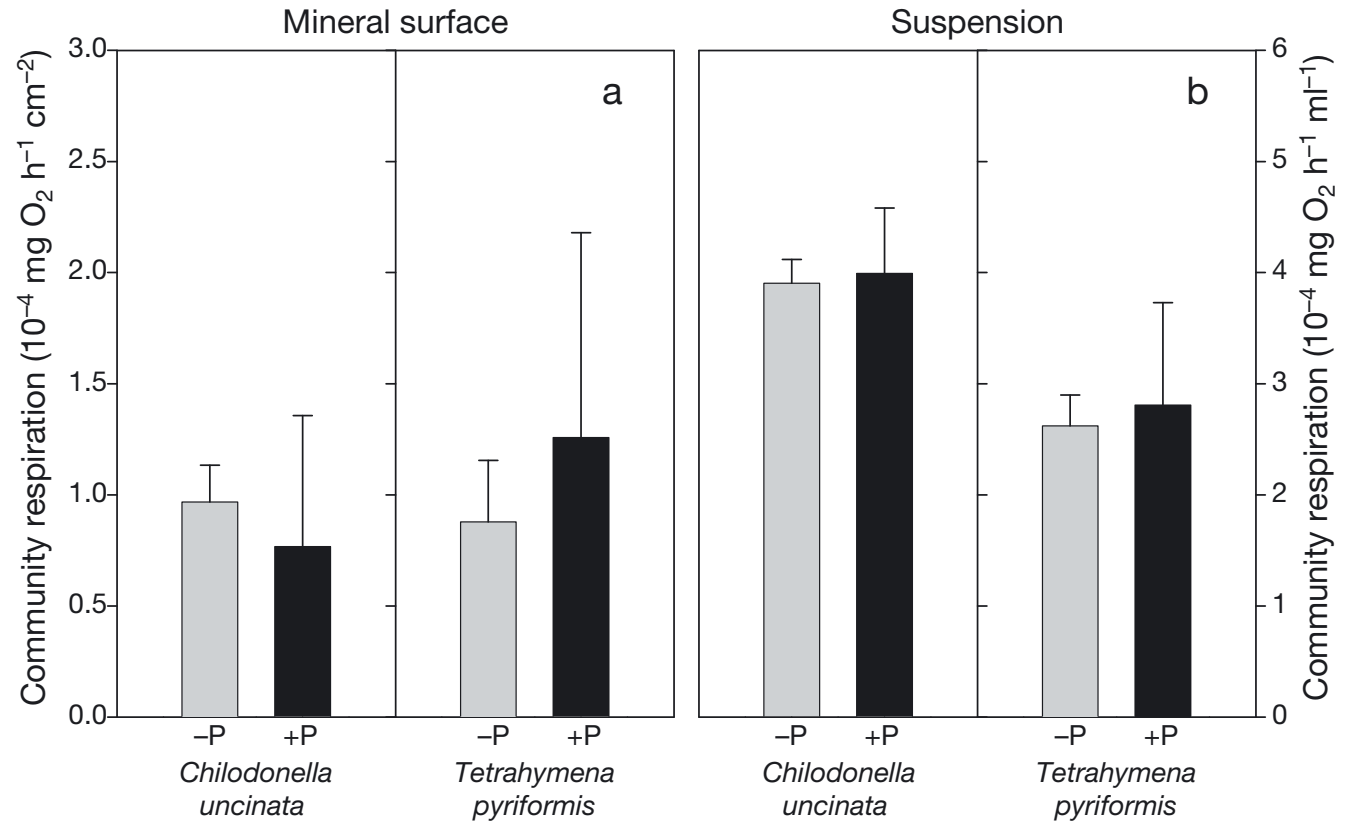

Fig. 2. Community respiration of (a) biofilms associated with the mineral surface and (b) suspended organisms after $7 \mathrm{~d}$ of incubation. Community respiration of the biofilm is related to surface area $\left(\mathrm{cm}^{-2}\right)$, and community respiration of the suspension is related to volume $\left(\mathrm{ml}^{-1}\right.$ ) (mean \pm standard deviation, $\mathrm{n}=5$ ). $-\mathrm{P}$ : protist-free; $+\mathrm{P}$ : protist-inhabited. Treatments were not significantly different ( $t$-test: $\mathrm{p}>0.05)$ 

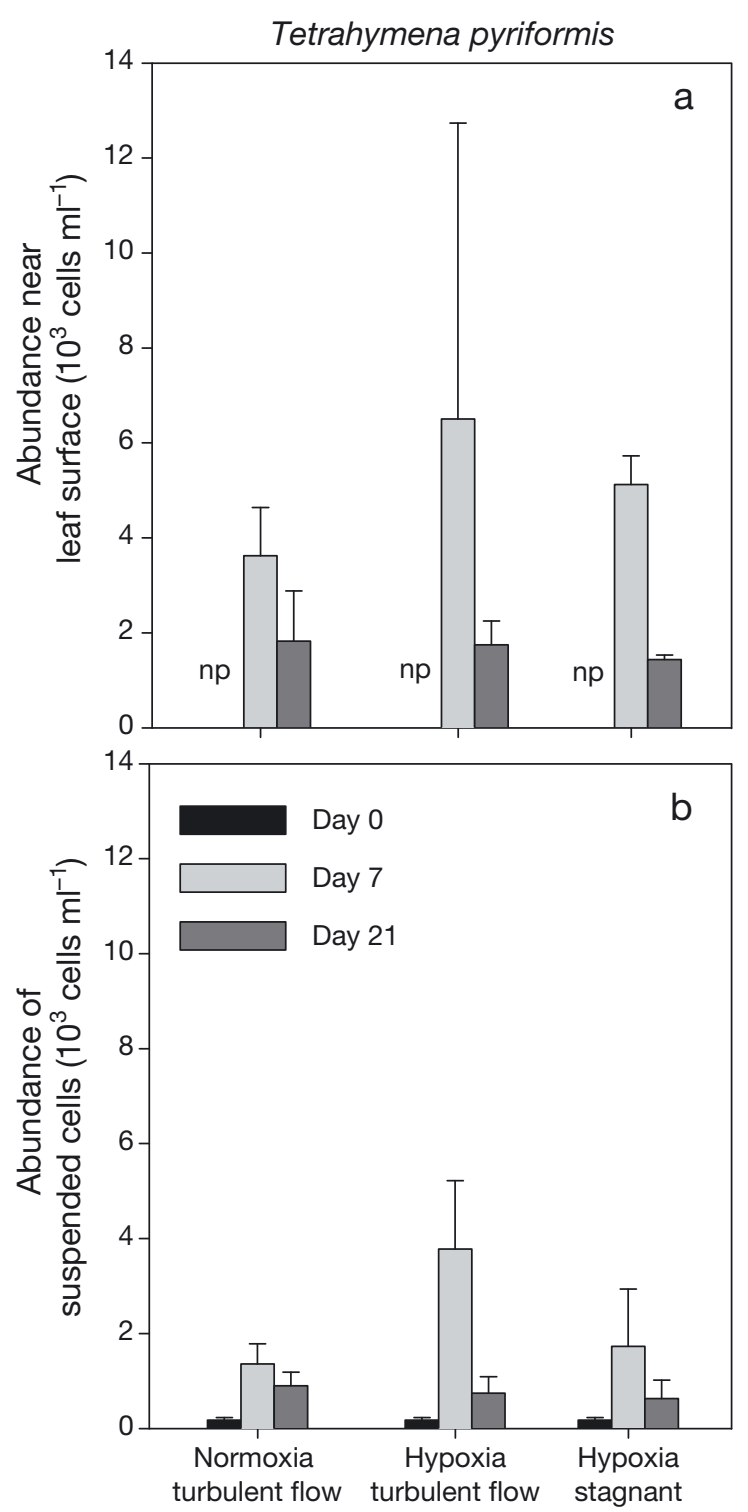

Fig. 3. Tetrahymena pyriformis. Abundance (a) associated with leaf discs (cells ml ${ }^{-1}$ ) and (b) in suspension (cells ml ${ }^{-1}$ ) at the start of the experiment and after 7 and $21 \mathrm{~d}$ of incubation (mean \pm standard deviation, $\mathrm{n}=3$ ). At Day 0 (start of the experiment), the leaves were colonized by fungi only. $\mathrm{np}$ : no protists

A significant effect of the factor combinations of OC/FC was observed for leaf-associated bacteria at Day 7 but not at Day 21 (Table 3). Bacterial abundance associated with leaves was highest under normoxia and turbulent flow, reaching $1.4 \times 10^{7} \pm 0.4 \times$ $10^{7}$ cells $\mathrm{cm}^{-2}$ compared to the other 2 treatments (Fig. 4a). Under hypoxia and stagnant conditions, the abundance of leaf-associated bacteria remained at a mean of $0.6 \times 10^{7}$ cells $\mathrm{cm}^{-2}$ during the $21 \mathrm{~d}$. The abundance of leaf-associated bacteria was not affected by Tetrahymena pyriformis (Table 3).
However, the suspended bacteria were 10.7-, 2.3-, and 3.2-fold less abundant in the treatments with Tetrahymena pyriformis under normoxia and turbulent flow, hypoxia and turbulent flow, and hypoxia and stagnant conditions at Day 7 , respectively (Fig. 4b). The abundance of suspended bacteria decreased in the protist-free treatment from Day 7 to Day 21. No such trend was observed in the treatments with T. pyriformis. The differences in the number of suspended bacteria between the protist-free and protist-inhabited treatments were less pronounced after $21 \mathrm{~d}$ and diminished under hypoxia and stagnant conditions.

The leaves colonized with the fungus had an $\mathrm{AFDM}_{\text {initial }}$ of $4.0 \mathrm{mg} \mathrm{cm}^{-2}$, which corresponded to an $\mathrm{AFDM}_{\text {initial }}$ content of $93.9 \pm 4.5 \%$. After $7 \mathrm{~d}$ of $\mathrm{co}-$ cultivation, a mean of $49.0 \pm 3.5 \%$ of leaf $\mathrm{AFDM}_{\text {initial }}$ remained, irrespective of the treatment (Fig. 5a). No further mass loss was detected during the $21 \mathrm{~d}$ incubation period. The presence of protist cells or the factor combinations of OC/FC had no significant effect

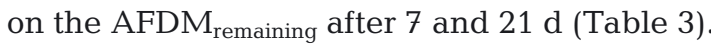

\section{Potential community respiration in the leaf litter experiment}

Under all of the factor combinations studied, the $\mathrm{pCR}_{\mathrm{LA}}$ was higher after $7 \mathrm{~d}$ than after $21 \mathrm{~d}$ of incubation (Fig. 5b). The presence of Tetrahymena pyriformis significantly affected the $\mathrm{pCR}_{\mathrm{LA}}$ at Day 7 and 21 , respectively (Table 3 ). The greatest difference was detected under the factor combination of hypoxia and stagnant conditions after $7 \mathrm{~d}$ of incubation, with the highest $\mathrm{pCR}_{\mathrm{LA}}$ in the presence of $T$. pyriformis of $4.4 \times 10^{-2} \pm 0.7 \times 10^{-2} \mathrm{mg} \mathrm{O}_{2} \mathrm{~cm}^{-2} \mathrm{~h}^{-1}$ (Fig. 5b). The $\mathrm{pCR}_{\mathrm{LA}}$ was 1.3-fold higher in the presence of T. pyriformis than in the protist-free treatment ( $t$-test: $\mathrm{p}<$ 0.05). At Day 21 , the $\mathrm{pCR}_{\mathrm{LA}}$ was not altered by T. pyriformis under hypoxia and stagnant conditions. However, at Day 21, T. pyriformis caused a 2.9- and 1.5fold higher $\mathrm{pCR}_{\mathrm{LA}}$ under the factor combinations of normoxia and turbulent flow as well as hypoxia and turbulent flow, respectively ( $t$-test: $\mathrm{p}<0.05$; Fig. 5a). The variances of community respiration rates in protist-inhabited and protist-free treatments were not significantly different ( $F$-test: $\mathrm{p}>0.05)$.

\section{DISCUSSION}

Despite the presence of protists, the community respiration of biofilms at mineral surfaces was com- 
Table 3. Two-factorial ANOVA design for the leaf litter experiment. The effects of Tetrahymena pyriformis and the factor combination of oxygen concentration/flow conditions (OC/FC) on abundance of leaf-associated bacteria, abundance of suspended bacteria, $\mathrm{AFDM}_{\text {remaining }}$ and leaf-associated community respiration rates $\left(\mathrm{pCR}_{\mathrm{LA}}\right)$, were tested at Days 7 and 21 (see Figs. 4 \& 5). SS: sum of squares; df: degrees of freedom; OC: oxygen concentration; FC: flow condition; AFDM: ash-free dry mass. ${ }^{*} \mathrm{p}<0.05 ;{ }^{* *} \mathrm{p}<0.01$

\begin{tabular}{|c|c|c|c|c|c|c|c|c|}
\hline & \multirow[b]{2}{*}{ df } & \multicolumn{3}{|c|}{ Day 7} & \multirow[b]{2}{*}{ df } & \multirow{2}{*}{\multicolumn{2}{|c|}{$\begin{array}{l}\text { Day } 21 \\
\text { SS } \quad F \text {-value }\end{array}$}} & \multirow[b]{2}{*}{$\mathrm{p}$} \\
\hline & & SS & $F$-value & $p$ & & & & \\
\hline \multicolumn{9}{|c|}{ Abundance of leaf-associated bacteria } \\
\hline Protist & 1 & $2.43 \times 10^{13}$ & 1.817 & 0.203 & 1 & $1.51 \times 10^{13}$ & 0.371 & 0.554 \\
\hline $\mathrm{OC} / \mathrm{FC}$ & 2 & $1.13 \times 10^{14}$ & 4.207 & $0.041^{*}$ & 2 & $2.17 \times 10^{14}$ & 2.669 & 0.110 \\
\hline $\begin{array}{l}\text { Protist } \\
\times \text { OC/FC }\end{array}$ & 2 & $6.03 \times 10^{13}$ & 2.254 & 0.148 & 2 & $4.51 \times 10^{12}$ & 0.056 & 0.946 \\
\hline Residuals & 12 & $1.60 \times 10^{14}$ & & & 12 & $4.88 \times 10^{14}$ & & \\
\hline \multicolumn{9}{|c|}{ Abundance of suspended bacteria } \\
\hline Protist & 1 & $6.59 \times 10^{14}$ & 8.852 & $0.012^{* *}$ & * 1 & $2.04 \times 10^{12}$ & 2.959 & 0.111 \\
\hline $\mathrm{OC} / \mathrm{FC}$ & 2 & $1.24 \times 10^{14}$ & 0.830 & 0.460 & 2 & $1.34 \times 10^{12}$ & 0.974 & 0.406 \\
\hline $\begin{array}{l}\text { Protist } \\
\times \text { OC/FC }\end{array}$ & 2 & $2.15 \times 10^{14}$ & 1.445 & 0.274 & 2 & $5.92 \times 10^{11}$ & 0.430 & 0.660 \\
\hline Residuals & 12 & $8.93 \times 10^{14}$ & & & 12 & $8.26 \times 10^{12}$ & & \\
\hline \multicolumn{9}{|c|}{ AFDM $_{\text {remaining }}$} \\
\hline Protist & 1 & $1.04 \times 10^{-3}$ & 0.144 & 0.711 & 1 & $2.75 \times 10^{-3}$ & 0.161 & 0.695 \\
\hline $\mathrm{OC} / \mathrm{FC}$ & 2 & $4.70 \times 10^{-3}$ & 0.326 & 0.728 & 2 & $3.01 \times 10^{-3}$ & 0.088 & 0.916 \\
\hline $\begin{array}{l}\text { Protist } \\
\times \text { OC/FC }\end{array}$ & 2 & $1.05 \times 10^{-2}$ & 0.730 & 0.502 & 2 & $2.67 \times 10^{-2}$ & 0.784 & 0.479 \\
\hline Residuals & 12 & $8.65 \times 10^{-2}$ & & & 12 & $2.05 \times 10^{-1}$ & & \\
\hline \multicolumn{9}{|l|}{$\mathbf{p C R}_{\mathrm{LA}}$} \\
\hline Protist & 1 & $2.39 \times 10^{-4}$ & 6.088 & $0.030^{*}$ & 1 & $2.55 \times 10^{-4}$ & 15.174 & $0.002^{* *}$ \\
\hline $\mathrm{OC} / \mathrm{FC}$ & 2 & $7.05 \times 10^{-5}$ & 0.899 & 0.433 & 2 & $2.64 \times 10^{-4}$ & 7.851 & $0.007^{* *}$ \\
\hline $\begin{array}{l}\text { Protist } \\
\times \mathrm{OC} / \mathrm{FC}\end{array}$ & 2 & $5.28 \times 10^{-5}$ & 0.674 & 0.528 & 2 & $1.05 \times 10^{-4}$ & 3.138 & 0.080 \\
\hline Residuals & 12 & $4.70 \times 10^{-4}$ & & & 12 & $2.02 \times 10^{-4}$ & & \\
\hline
\end{tabular}

bial biomass (Suberkropp \& Klug 1976, Baldy \& Gessner 1997). Furthermore, leaf-associated bacteria benefit from the products of the extracellular enzyme activities of leaf-degrading fungi (Baschien et al. 2009). Hence, leaf-associated microorganisms in our experiment did not seem to be as limited by resources as the biofilms on mineral surfaces.

\section{Activity of biofilm communities at mineral surfaces seemed to be unaffected by protists}

Our results indicated that the function of the communities, i.e. carbon and nutrient flow, of protist-inhabited microbial biofilms was comparable to that of protist-free bacterial biofilms, despite the lower biomass of biofilm bacteria. Because excessive biofilm biomass per se can have negative effects, e.g. due to local oxygen depletion, protists have the potential to optimize the structure-function relationship in biofilms.

The bacterial abundance and biomass of biofilms were significantly reduced by grazing protists. Protists are known to efficiently graze biofilm parable to that of protist-free biofilms. In contrast, the potential activity of leaf-associated microbial communities was modulated in the presence of protists. Microbial activity in the pelagic zone of marine systems, marine sediments, and soils is stimulated in the presence of protists (Johannes 1965, Sherr \& Sherr 1984, Bonkowski 2004, Tso \& Taghon 2006). We suggest that the discrepancy between the community respiration associated with a mineral surface and leaf litter was related to the available carbon and nutrient resources. Initial biofilms grown at mineral surfaces receive nutrients and organic carbon mainly from the overflowing water (Lock 1979, Mickleburgh et al. 1984, Battin et al. 1999). In our experiments, the growth of young biofilms at mineral surfaces was controlled by the dissolved organic carbon of the medium. In contrast, leaf litter provides both space and a carbon source for the associated microbial organisms. Leaf litter associated fungi possess the enzymes to degrade the polymers of the leaf components and can turn refractory compounds into micro- bacteria if bacteria lack adequate defense strategies (Matz \& Kjelleberg 2005, Weitere et al. 2005). Grazing-induced changes that result in small-sized inactive bacteria (Hahn \& Höfle 2001) can be excluded because the bacterial biovolume was significantly larger in the presence of Chilodonella uncinata than in the protist-free biofilms. Raptorial feeders that remove biofilm patches (Weitere et al. 2005, Böhme et al. 2009) provide new colonization sites for dispersing bacteria. Suspension feeders, such as Tetrahymena, can detach loosely associated biofilm bacteria (Parry 2004) due to their strong feeding currents. However, the contrasting protist actions might have resulted in limited effects on the community respiration of microbial biofilms.

Both the protistan and bacterial abundance of the studied biofilms at mineral surfaces was comparable to that of young stream biofilms (Schönborn 1981, Arndt et al. 2003, Besemer et al. 2007, Risse-Buhl \& Küsel 2009, Pohlon et al. 2010) but was about 10-fold (Schönborn 1982, Ackermann et al. 2011) and 1 to 2 


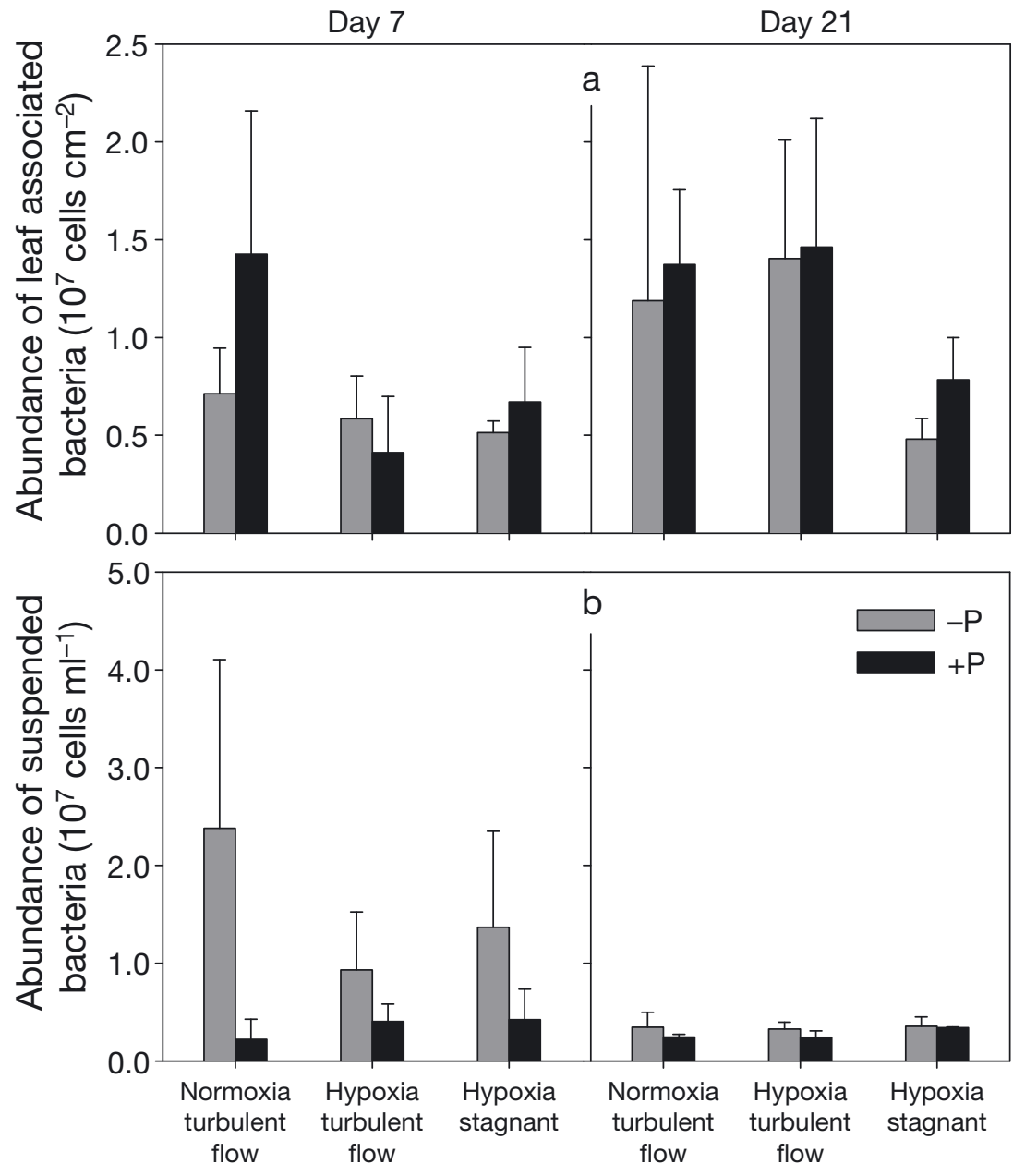

Fig. 4. Abundance of DPQ bacterial community (a) associated with leaf discs (cells $\mathrm{cm}^{-2}$ ) and (b) in suspension (cells ml-1) after 7 and $21 \mathrm{~d}$ of incubation (mean \pm standard deviation, $\mathrm{n}=3$ ). Results of the statistical analysis are presented in Table 3. $-\mathrm{P}$ : protist-free; $+\mathrm{P}$ : protist-inhabited additional architectural structures induced by grazers or biofilm growth and an autotrophic component could modulate the impact of protist species on biofilm activity.

\section{Protists modulate microbial activity associated with leaf litter}

Our results proved that the presence of Tetrahymena pyriformis positively affected the potential leaf-associated microbial activity. The impact of $T$. pyriformis on potential leaf-associated microbial community respiration varied with time and treatment. After $7 \mathrm{~d}$, the suspension-feeding T. pyriformis stimulated the potential leaf-associated community respiration under all of the studied factor combinations of oxygen concentrations and flow conditions. However, potential leaf-associated community respiration was stimulated in the presence of $T$. pyriformis under turbulent flow (normoxic and hypoxic conditions) but not under hypoxic and stagnant conditions after $21 \mathrm{~d}$. We assume that these differences were caused by the different abundances of $T$. pyriformis, which were highest after $7 \mathrm{~d}$ and decreased later on. After $7 \mathrm{~d}$, bacteria probably profited from fungal-released nutrients and provided optimal conditions for orders of magnitude (Besemer et al. 2007, Augspurger et al. 2008) lower, respectively than those observed in more mature stream biofilms. During biofilm development, architectural structures, such as microcolonies, ripples, and streamers, are typically formed that increase habitat diversity and area for colonizing microorganisms (Besemer et al. 2007, 2009). In addition to the spatial heterogeneity, typical components of stream biofilms, such as heterotrophic (bacteria, flagellates, amoeba, and ciliates) and autotrophic (prokaryotes and algae) species (Arndt et al. 2003) add further complexity. In turn, habitat heterogeneity and/or complexity stimulate benthic respiration (Cardinale et al. 2002). The addition of protists to a biofilm increases its spatial and temporal heterogeneity (Lawrence \& Snyder 1998), which presumably caused the high variability of the community respiration of protist-inhabited biofilms. Hence, the development of the suspension-feeding protists. Hence, the high microbial activity during the initial stages of leaf decomposition in our experiment might have caused hypoxic micro-zones near the leaf surface, as was reported by Eichem et al. (1993). Consequently, abundant T. pyriformis cells in the studied microcosms might have induced micro-currents by movement and filtration activity, which enhanced the advective transport of oxygen towards the leafassociated microbial community under hypoxic and stagnant conditions (cf. Glud \& Fenchel 1999). Moreover, organic acids excreted from protist cells stimulate microbial activity under hypoxic conditions (Biagini et al. 1998). After $21 \mathrm{~d}$, up to 5-fold fewer $T$. pyriformis cells were present in the microcosms compared to Day 7. Micro-zones of $<1 \mathrm{mg} \mathrm{O}_{2} \mathrm{ml}^{-1}$ presumably induced by the initially high microbial activity under hypoxic and stagnant conditions might 

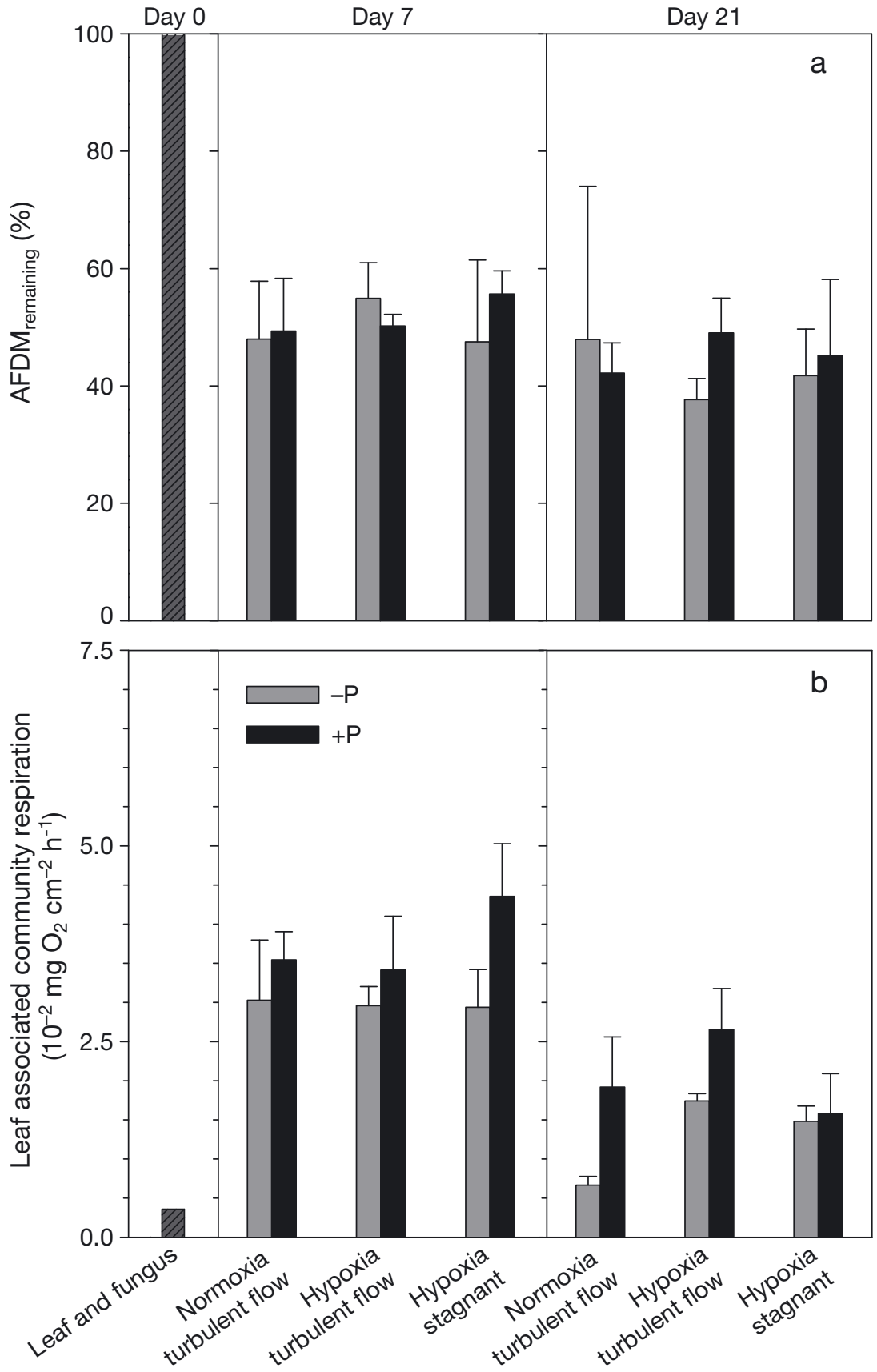

Fig. 5. (a) Fraction of remaining ash-free dry mass (AFDM) and (b) leaf-associated community respiration rate per leaf area of leaf discs previously colonized by fungi (Day 0), incubated with a DPQ bacterial community $(-\mathrm{P})$ or with a DPQ bacterial community and Tetrahymena pyriformis $(+\mathrm{P})$ under combinations of normoxia and turbulent flow, hypoxia and turbulent flow, and hypoxia and stagnant conditions after 7 and $21 \mathrm{~d}$ of incubation (mean \pm standard deviation, $\mathrm{n}=3$ ). Organic matter content of initial leaves colonized with the fungi averaged $93.9 \pm 4.5 \%$. Results of the statistical analysis are presented in Table 3

have caused environmental stress to $T$. pyriformis (Pace \& Ireland 1945, Foissner et al. 1994), and reproduction of the protist ceased. At this stage, the microcurrents or excretion products arising from fewer
T. pyriformis cells did not seem to be sufficient to modulate the leaf-associated microbial activity under hypoxic and stagnant conditions.

Regardless of the presence of Tetrahymena pyriformis, the potential leaf-associated microbial activity was higher after $7 \mathrm{~d}$ than after $21 \mathrm{~d}$ of incubation. Nutrient limitation in the microcosms can be excluded because the medium was replaced weekly. Presumably, the $7 \mathrm{~d}$ incubation period matched the period of maximum exploitation of the leaf material, as indicated by the high potential community respiration and leaf mass loss. The subsequent decrease in potential community respiration and leaf mass loss may indicate an advanced phase of microbial leaf decay when degradation of more refractory long-chained carbon compounds, such as lignin and cellulose, might have slowed the microbial activity associated with the leaf. Typical temporal dynamics of leafassociated community respiration during leaf colonization and processing in streams corroborate these assumptions (Eichem et al. 1993, Simon \& Benfield 2001, Schlief 2004). However, autoclaving and leaching the leaves before the experiment started could have altered the leaf quality composition and, thus, the microbial colonization, activity, and leaf processing.

Although protists positively affected the leaf-associated community respiration, mass loss of the leaf discs preconditioned with fungi was not stimulated. However, microbial leaf litter decomposition was shown to be stimulated in the presence of streamcolonizing flagellates and ciliates (Ribblett et al. 2005). Moreover, for marine environments, studies with eelgrass, hay, and macrophyte leaves proved that decomposition rates are positively influenced by protists (Harrison \& Mann 1975, Fenchel \& Harrison 1976, Sherr et al. 1982). There are 3 possible reasons for the lack of stimulated leaf mass loss in our study. First, in particular, the leaf-associated bacterial community was stimulated by $T$. pyriformis 
but did not produce effective degradative enzymes for the leaf decomposition process (Schneider et al. 2010). Hence, an increased community respiration was recorded, but there was no effect on leaf mass loss. Second, stimulated by grazing by T. pyriformis, fungal biomass increased and, in turn, balanced the losses of leaf mass and diminished differences between treatments. The fungal biomass was not determined within the present study but might support this assumption. Third, microbially mediated leaf decay is generally a slow process (Webster \& Benfield 1986). The decomposition of long-chained carbon compounds (i.e. cellulose) is mediated by a diverse consortium of aerobic and anaerobic cellulolytic bacteria and fungi (Cummings \& Stewart 1994, Leschine 1995, Barlaz 1997). The experimental period of $21 \mathrm{~d}$ was possibly too short to allow the development of the bacterial consortium that mediate leaf decomposition, and hence, protist-induced effects on leaf mass loss could not be observed. The experiment of Ribblett et al. (2005), which proved enhanced microbial litter decomposition in the presence of protists, was conducted during a $120 \mathrm{~d}$ incubation period. We suggest that a longer incubation period should be investigated and additional parameters of leaf quality (e.g. fungal biomass and contents of lignin and cellulose) should be measured in studies that aim to detect protist-stimulated leaf litter decomposition.

On a macroscopic scale, hypoxic conditions may occur in running waters at sites with low advection where organic material can accumulate, e.g. during low-flow or drought periods with simultaneous high litter input (Acuña et al. 2005, Schlief \& Mutz 2009, 2011). Such periods are typically observed in warmer climate regions (e.g. Boulton 2003, Acuña et al. 2005, Canhoto \& Laranjeira 2007, Bond et al. 2008) and will occur more frequently in temperate climate regions in the near future (Andersen et al. 2006, Krysanova et al. 2008). Hence, protist-accelerated microbial activity may be of increasing significance for initial stages of microbially mediated leaf decomposition in drought-affected streams. Further, it has been proved that protists increase the efficiency of activated sludge plants and rotating biological contactors by grazing on bacteria and increasing the flocculation of organic particles colonized by bacteria (Curds 1963, Curds et al. 1968, Kinner \& Curds 1987). Our finding that protists modulate the activity of surface-associated microbial communities is of broad relevance because surface-associated bacteria mediate the degradation and flux of matter within both industrial facilities and aquatic ecosystems.
Acknowledgements. We thank T. Wolburg, M. Knie, and J. Jander for technical support. This work was supported by grants from the German Science Foundation (DFG) to J.S., M.M. and M.W. (Priority Program 1162 AQUASHIFT) and to M.M. and U.R.-B. (Collaborative Research Centre TRR38).

\section{LITERATURE CITED}

Abelho M, Cressa C, Graça MAS (2005) Microbial biomass, respiration and decomposition of Hura crepitans L. (Euphobiacea) leaves in a tropical stream. Biotropica 37 : 397-402

Ackermann B, Esser M, Scherwass A, Arndt H (2011) Longterm dynamics of microbial biofilm communities of the River Rhine with special references to ciliates. Int Rev Hydrobiol 96:1-19

Acuña V, Muñoz I, Giorgi A, Omella M, Sabater F, Sabater S (2005) Drought and post-drought recovery cycles in an intermittent Mediterranean stream: structural and functional aspects. J N Am Benthol Soc 24:919-933

Adl SM, Simpson AGB, Farmer MA, Andersen RA and others (2005) The new higher level classification of eukaryotes with emphasis on the taxonomy of protists. J Eukaryot Microbiol 52:399-451

Andersen HE, Kronvang B, Larsen SE, Hoffmann CC, Jensen TS, Rasmussen E (2006) Climate-change impacts on hydrology and nutrients in a Danish lowland river basin. Sci Total Environ 365:223-237

Arndt H, Schmidt-Denter K, Auer B, Weitere M (2003) Protozoans and biofilms. In: Krumbein WE, Paterson DM, Zavarzin GA (eds) Fossil and recent biofilms. Kluwer Academic, Dordrecht, p 161-179

Augspurger C, Gleixner G, Kramer C, Küsel K (2008) Tracking carbon flow in a 2-week-old and 6-week-old stream biofilm food web. Limnol Oceanogr 53:642-650

Baldy V, Gessner MO (1997) Towards a budget of leaf litter decomposition in a first-order woodland stream. CR Acad Sci Paris 320:747-758

Barlaz MA (1997) Microbial studies of landfills and anaerobic refuse decomposition. ASM Press, Washington, DC

Baschien C, Rode G, Böckelmann U, Götz P, Szewzyk U (2009) Interactions between hyphosphere-associated bacteria and the fungus Cladosporium herbarum on aquatic leaf litter. Microb Ecol 58:642-650

> Battin TJ, Butturini A, Sabater F (1999) Immobilization and metabolism of dissolved organic carbon by natural sediment biofilms in a Mediterranean and temperate stream. Aquat Microb Ecol 19:297-305

Besemer K, Singer G, Limberger R, Chlup AK and others (2007) Biophysical controls on community succession in stream biofilms. Appl Environ Microbiol 73:4966-4974

Besemer K, Hödl I, Singer G, Battin TJ (2009) Architectural differentiation reflects bacterial community structure in stream biofilms. ISME J 3:1318-1324

> Biagini GA, Finlay BJ, Lloyd D (1998) Protozoan stimulation of anaerobic microbial activity: enhancement of the rate of terminal decomposition of organic matter. FEMS Microbiol Ecol 27:1-8

Bjelke U (2005) Processing of leaf matter by lake-dwelling shredders at low oxygen concentrations. Hydrobiologia 539:93-98

> Böhme A, Risse-Buhl U, Küsel K (2009) Protists with different feeding modes change biofilm morphology. FEMS Microbiol Ecol 69:158-169 
Bond NR, Lake PS, Arthington AH (2008) The impacts of drought on freshwater ecosystems: an Australian perspective. Hydrobiologia 600:3-16

Bonkowski M (2004) Protozoa and plant growth: the microbial loop in soil revisited. New Phytol 162:617-631

Bott TL, Kaplan LA (1989) Densities of benthic protozoa and nematodes in a Piedmont stream. J N Am Benthol Soc 8: 187-196

Boulton AJ (2003) Parallels and contrasts in the effects of drought on stream macroinvertebrate assemblages. Freshw Biol 48:1173-1185

Canhoto C, Laranjeira C (2007) Leachates of Eucalyptus globulus in intermittent streams affect water parameters and invertebrates. Int Rev Hydrobiol 92:173-182

> Cardinale BJ, Palmer MA, Swan CM, Brooks SS, Poff NL (2002) The influence of substrate heterogeneity on biofilm metabolism in a stream ecosystem. Ecology (USA) 83:412-422

Chauvet E, Suberkropp K (1998) Temperature and sporulation of aquatic hyphomycetes. Appl Environ Microbiol 64:1522-1525

> Chen X, Stewart PS (2000) Biofilm removal caused by chemical treatments. Water Res 34:4229-4233

Cummings SP, Stewart CS (1994) A study of cellulose degradation in landfills. Rowert Research Institute, Aberdeen

> Curds CR (1963) The flocculation of suspended matter by Paramecium caudatum. J Gen Microbiol 33:357-363

Curds CR, Cockburn A, Vandyke JM (1968) An experimental study of the role of the ciliated protozoa in the activated sludge process. Water Pollut Control 67:312-329

de Beer D, Stoodley P, Lewandowski Z (1996) Liquid flow and mass transport in heterogeneous biofilms. Water Res 30:2761-2765

Dufrêne M, Legendre P (1997) Species assemblages and indicator species: the need for a flexible asymmetrical approach. Ecol Monogr 67:345-366

Eichem AC, Dodds WK, Tate CM, Edler C (1993) Microbial decomposition of elm and oak leaves in a karst aquifer. Appl Environ Microbiol 59:3592-3596

Eisenmann H, Harms H, Meckenstock R, Meyer EI, Zehnder AJB (1998) Grazing of a Tetrahymena sp. on adhered bacteria in percolated columns monitored by in situ hybridization with fluorescent oligonucleotide probes. Appl Environ Microbiol 64:1264-1269

Fenchel T, Harrison P (1976) The significance of bacterial grazing and mineral cycling for the decomposition of particulate detritus. In: Anderson JM, McFadyen A (eds) The role of terrestrial and aquatic organisms in decomposition processes. Blackwell, Oxford, p 285-299

Fenchel T, Finlay BJ, Giannì A (1989) Microaerophily in ciliates: responses of an Euplotes species (hypotrichida) to oxygen tension. Arch Protistenkd 137:317-330

Finlay BJ, Esteban GF (1998) Freshwater protozoa: biodiversity and ecological function. Biodivers Conserv 7 : 1163-1186

Finlay BJ, Esteban GF (2009) Oxygen sensing drives predictable migrations in a microbial community. Environ Microbiol 11:81-85

Foissner W, Blatterer H, Berger H, Kohmann F (1991) Taxonomische und Ökologische Revision der Ciliaten des Saprobiensystems - Band I: Cyrtophorida, Oligotrichida, Hypotrichida, Colpodea. Bayerisches Landesamt für Wasserwirtschaft, Munich

Foissner W, Berger H, Kohmann F (1994) Taxonomische und Ökologische Revision der Ciliaten des Saprobiensys- tems - Band III: Hymenostomata, Prostomatida, Nassulida. Bayerisches Landesamt für Wasserwirtschaft, Munich

Franco C, Esteban GF, Tellez C (1998) Colonization and succession of ciliated protozoa associated with submerged leaves in a river. Limnologica 28:275-283

Gams W, Hoekstra ES, Aptroot A (1998) CBS course of mycology. Centraalbureau voor Schimmelcultures, Baarn

- Geesey GG, Mutch R, Costerton JW, Green RB (1978) Sessile bacteria: an important component of microbial population in small mountain streams. Limnol Oceanogr 23: 1214-1223

Glud RN, Fenchel T (1999) The importance of ciliates for interstitial solute transport in benthic communities. Mar Ecol Prog Ser 186:87-93

> Hahn MW, Höfle MG (2001) Grazing of protozoa and its effect on populations of aquatic bacteria. FEMS Microbiol Ecol 35:113-121

- Harrison PG, Mann KH (1975) Detritus formation from eelgrass Zostera marina L: relative effects of fragmentation, leaching, and decay. Limnol Oceanogr 20:924-934

Hausmann K, Hülsmann N, Radek R (2003) Protistology. E. Schweizerbart'sche Verlagsbuchhandlung, Stuttgart

> Hieber M, Gessner MO (2002) Contribution of stream detrivores, fungi, and bacteria to leaf breakdown based on biomass estimates. Ecology (USA) 83:1026-1038

Jerome CA, Montagnes DJS, Taylor FJR (1993) The effect of the QPS and Lugol's and Bouin's fixative on cell size: a more accurate estimate of ciliate species biomass. J Eukaryot Microbiol 40:254-259

> Johannes RE (1965) Influence of marine protozoa on nutrient regeneration. Limnol Oceanogr 10:434-442

> Kinner NE, Curds CR (1987) Development of protozoan and metazoan communities in rotating biological contactor biofilms. Water Res 21:481-490

Krysanova V, Vetter T, Hattermann FF (2008) Detection of change in the drought frequency in the Elbe basin: comparison of three methods. Hydrol Sci J 53:519-537

Lawrence JR, Snyder RA (1998) Feeding behavior and grazing impacts of a Euplotes sp. on attached bacteria. Can J Microbiol 44:623-629

Leschine SB (1995) Cellulose degradation in anaerobic environments. Annu Rev Microbiol 49:399-426

> Lock MA (1979) The effect of flow patterns on uptake of phosphorus by river periphyton. Limnol Oceanogr 24: 376-383

Lock MA, Wallace RR, Costerton JW, Ventullo RM, Charlton SE (1984) River epilithon: toward a structural-functional model. Oikos 42:10-22

Loferer-Krößbacher M, Klima J, Psenner R (1998) Determination of bacterial cell dry mass by transmission electron microscopy and densitometric image analysis. Appl Environ Microbiol 64:688-694

Lynn DH, Small EB (2002) Phylum Ciliophora. In: Lee JJ, Bradbury PC, Leedale GF (eds) The illustrated guide to the protozoa. Society of Protozoologists, Lawrence, KS, p 371-676

Matz C, Kjelleberg S (2005) Off the hook-how bacteria survive protozoan grazing. Trends Microbiol 13:302-307

Mickleburgh S, Lock MA, Ford TE (1984) Spatial uptake of dissolved organic carbon in river beds. Hydrobiologia 108:115-119

Nixdorf B, Jander J (2003) Bacterial activities in shallow lakes - a comparison between extremely acidic and alkaline eutrophic hard water lakes. Hydrobiologia 506509:697-705 
Norf H, Arndt H, Weitere M (2009) Effects of resource supplements on mature ciliate biofilms: an empirical test using a new type of flow cell. Biofouling 25:769-778

Pace DM, Ireland RL (1945) The effects of oxygen, carbon dioxide, and pressure on growth in Chilomonas paramecium and Tetrahymena geleii furgason. J Gen Physiol 28: $547-557$

Parry JD (2004) Protozoan grazing of freshwater biofilms. Adv Appl Microbiol 54:167-196

Pohlon E, Marxsen J, Küsel K (2010) Pioneering bacterial and algal communities and potential extracellular enzyme activities of stream biofilms. FEMS Microbiol Ecol 71:364-373

Porter KG, Feig YS (1980) The use of DAPI for identifying and counting aquatic microflora. Limnol Oceanogr 25: 943-948

Queck SY, Weitere M, Moreno AM, Rice SA, Kjelleberg S (2006) The role of quorum sensing mediated developmental traits in the resistance of Serratia marcescens biofilms against protozoan grazing. Environ Microbiol 8: 1017-1025

Ribblett SG, Palmer MA, Coats DW (2005) The importance of bacterivorous protists in the decomposition of stream leaf litter. Freshw Biol 50:516-526

Risse-Buhl U, Küsel K (2009) Colonization of biofilm associated ciliate morphotypes at different flow velocities. Eur J Protistol 45:64-76

Romaní AM, Guasch H, Muñoz I, Ruana J and others (2004) Biofilm structure and function and possible implications for riverine DOC dynamics. Microb Ecol 47:316-328

Schlief J (2004) Leaf associated microbial activities in a stream affected by acid mine drainage. Int Rev Hydrobiol 89:467-475

Schlief J, Mutz M (2007) Response of aquatic leaf associated microbial communities to elevated leachate DOC: a microcosm study. Int Rev Hydrobiol 92:146-155

Schlief J, Mutz M (2009) Effect of sudden flow reduction on the decomposition of Alder leaves (Alnus glutinosa [L.] Gaertn.) in a temperate lowland stream: a mesocosm study. Hydrobiologia 624:205-217

Schlief J, Mutz M (2011) Leaf decay processes during and after a supra-seasonal hydrological drought in a temperate lowland stream. Int Rev Hydrobiol 96:633-655

Schneider T, Gerrits B, Gassmann R, Schmid E and others (2010) Proteome analysis of fungal and bacterial involvement in leaf litter decomposition. Proteomics 10: 1819-1830

Editorial responsibility: Tom Battin, Vienna, Austria
Schönborn W (1981) Die Ziliatenproduktion eines Baches. Limnologica 13:203-212

Schönborn W (1982) Die Ziliatenproduktion in der mittleren Saale. Limnologica 14:329-346

Sherr BF, Sherr EB (1984) Role of heterotrophic protozoa in carbon and energy flow in aquatic ecosystems. In: Klug MJ, Reddy CA (eds) Current perspectives in microbial ecology. American Society for Microbiology, Washington, DC, p 412-423

Sherr BF, Sherr EB, Berman T (1982) Decomposition of organic detritus: a selective role for microflagellate protozoa. Limnol Oceanogr 27:765-769

Simon KS, Benfield EF (2001) Leaf and wood breakdown in cave stream. J N Am Benthol Soc 20:550-563

> Sobczak WV (1996) Epilithic bacterial responses to variations in algal biomass and labile dissolved organic carbon in water. J N Am Benthol Soc 15:143-154

Suberkropp K (2001) Fungal growth, production and sporulation during leaf decomposition in two streams. Appl Environ Microbiol 67:5063-5068

Suberkropp K, Klug MJ (1976) Fungi and bacteria associated with leaves during processing in a woodland stream. Ecology (USA) 57:707-719

Tso SF, Taghon GL (2006) Protozoan grazing increases mineralization of naphthalene in marine sediment. Microb Ecol 51:460-469

> Turley CM, Newell RC, Robins DB (1986) Survival strategies of two small marine ciliates and their role in regulating bacterial community structure under experimental conditions. Mar Ecol Prog Ser 33:59-70

Velji MI, Albright LJ (1993) Improved sample preparation for enumeration of aggregated aquatic substrate bacteria. In: Kemp PF, Sherr BF, Sherr EB, Cole JJ (eds) Aquatic microbial ecology. Lewis Publishers, Boca Raton, FL, p 139-142

Webster JR, Benfield EF (1986) Vascular plant breakdown in freshwater ecosystems. Annu Rev Ecol Syst 17:567-594

Weitere M, Bergfeld T, Rice SA, Matz C, Kjelleberg S (2005) Grazing resistance of Pseudomonas aeruginosa biofilms depends on type of protective mechanism, developmental stage and protozoan feeding mode. Environ Microbiol 7:1593-1601

> Wey JK, Scherwass A, Norf H, Arndt H, Weitere M (2008) Effects of protozoan grazing within river biofilms under semi-natural conditions. Aquat Microb Ecol 52:283-296

Willoughby LG, Archer JF (1973) The fungal spora of a freshwater stream and its colonization pattern on wood. Freshw Biol 3:219-239

Submitted: May 9, 2011; Accepted: March 21, 2012

Proofs received from author(s): April 25, 2012 